\title{
Intercultural Competence - Way to Solve the Problems of Today's World
}

\section{Roxana DOROBANȚU-DINA}

\begin{abstract}
This article highlights the need to form intercultural competence, which is closely in line with the dynamics of globalization and migration - so much publicized in recent years. Intercultural education is the study discipline included in the Romanian National Curriculum starting with 2017, which is taught in the sixth grade, this being the alternative to open communication, understanding, tolerance, interaction, solidarity and intercultural dialogue between peopleregardless of ethnicity, race, religion, social condition, etc. Based on theoretical and praxiological analysis regarding the formation of the intercultural competence to the students from the gymnasium classes, three stages imposed in the finalization of the pedagogical experiment are completed: finding, training and verification. The added value of the scientific research paper is supported by teacher training activities based on the theme presented, through the elaboration and application of the Initiation Guide in Education and Intercultural Competence. Increased attention was paid to the theoreticalapplied foundations that formed the basis for the elaboration and application of the Pedagogical Model for the formation of intercultural competence to the students from the gymnasium classes.
\end{abstract}

Keywords: culture, intercultural education, competence, intercultural competence.

JEL Code: I21, I 23

\section{Introduction}

Intercultural education is a relatively new field, which is referred to in the literature for the past 40 years. Romania's integration into the European

\footnotetext{
${ }^{1}$ Roxana DOROBANȚU-DINA, PhD student "Ion Creangă” State Pedagogical University, Education Sciences, Chisinau, MD. https://orcid.org/0000-0002-7216-6785. Email: scoala.iclazarescu@yahoo.com
} 
Union, on January 1, 2007 is one of the reasons why more and more attention is paid to interculturality.

Part of the "new education", along with education for sustainable development, education for the environment, education for health, financial education, intercultural education has had a very important role in shaping the human being since schooling. (Lupșa 2019).

At the moment mankind is facing a number of problems, of which we mention only: interethnic or interstate wars, epidemics, arms or human trafficking, natural disasters, fires, floods, migration, racist problems and religious fundamentalists, famine, proverty, etc. - and the modern man has to face all of these challenges; In the life of a people, culture and the intercultural approach have a decisive role on the formation of the next generation's personality. This is the reasoning behind this study, "Training intercultural competence for students in middle school."

Researching specialized works in fields such as history, sociology, psychology and pedagogy shows that intercultural issues and fundamentalistspiritual approach have led several times to trigger socio-economic conflicts, national or regional, which have forever marked the population. Thus, we argue that education and intercultural competence lead to the formation of a moral-civic behavior among students, based on knowledge of their own cultural values and those with whom they live, acceptance, understanding, integration, interaction and mutual respect. (Guţu, 2011; Guţu, 2014)

The phenomenon of globalization - as an action of transforming the world into a unit (Rus, Bota, 2002), directs our attention to the issue of interculturality, which becomes one of utmost importance and topicality. In the school environment, through formal, non-formal or informal activities intercultural education is an inexhaustible source of interaction and knowledge of one's own culture and the culture of those with whom people live, through which relationships of friendship, understanding and tolerance towards those belonging to another race, religion, culture, ethnicity, nationality, etc. are formed and developed. The school has an essential role in this sense, because only an educated person has an intercultural vision of the world and relationships with peers, without prejudices or stereotypes. According to specialized studies (Plugaru \& Păvălache, 2008), culture and interculturality are the terms that best define the relationships between people, 
regardless of ethnicity, nationality, skin color, religious affiliation, sex, age, socio-economic level or geographical positioning. Romania - the country at the crossroads between the West and the East has come into contact throughout its millennial history with cultural elements of several peoples: Turks, Tartars, Slavs, Poles, Bulgarians, Germans, Jews, Saxons, Szeklers, Hungarians, Roma (Malița, 2002); a series of words are preserved to this day in the Romanian vocabulary, and some cultural elements are reflected in customs, proverbs, sayings, legends, etc.

The phenomenon of migration in Romania is also part of the problems of today's world (Abdallah-Pretceille, 1999), (Hofstede, 1996), for which political leaders at European and international level must find solutions as soon as possible; the phenomenon of migration began in the nineteenth century and continues at a rapid pace. It could be said that it has intensified in the last 15 years, with a greater opening after 2007, the year of Romania's integration into the European Union. The main causes of immigration in our country are closely related to getting a job, raising a family or continuing studies. (Antonesei, 2001; Ciobanu \& Cozărescu, 2010)

In the hectic pace of daily life, marked by the phenomenon of globalization and migration - we say that the formation of intercultural competence of students in middle school is the main point of interest of the current National Curriculum. Referring to intercultural competence, the profile of the high school graduate is well defined by language skills, social and civic skills - which show solidarity, interaction, openness to cultural diversity, acceptance, tolerance and intercultural dialogue. (Chiş, 2005)

\section{Literature review}

The theoretical and praxiological research action undertaken by us, based on the specialized literature of researchers: Sadovei Papuc, Cristea and Cojocaru-Borozan, (2016), Sadovei, Cojocaru-Borozan, (2014), will lead to the formation of intercultural competence of students from middle school classes - making use of all the levers of the school institution: methods, means, free games, open communication, teamwork, artistic and sports activities school and extracurricular etc. An essential role is assigned by the teacher to social-charitable actions, leisure activities, thematic visits and 
excursions, inviting notable people from ethnicities or minorities, as examples of success and good practice, implementing educational miniprojects based on Erasmus-type experience exchange, through the EEA Financial Mechanism.

The school - through its teachers is meant to prepare students for successful integration into social and professional life. The rapid evolution of technology and digitalization that is expanding nationally and globally, undoubtedly lead to new cultural horizons. (Cebanu, 2014) The first beneficiaries of information that circulates rapidly from one corner of the world to another in online format are students. Today, people communicate spontaneously, see each other more easily, even if they have never interacted, find out news from any corner of the world about culture, habits, values and principles of life - computer support being the basis of all these facilities. Intercultural education learned empirically in the family and systematically continued in school, is the premise for success in intercultural communication (Goraş-Postică, 2003).

Thus, we support Batelaan's theory (Batelaan, 2003) regarding intercultural competence, which largely confirms our hypothesis, namely:

- implementation of a school curriculum aimed at specific skills based on globalization, and not on ethnocentrism;

- approaching student-centered activities, which stimulate critical thinking and appreciation of diversity. (Ciscai, 2008).

According to the New National Curriculum for primary and secondary education published in 2017 - the profile of the high school graduate includes the training of these social and intercultural skills, which support the integration of young people in social and professional life. In fact, according to specialized studies in psychology (Cuznețov, 2010, 2013), pedagogy (Cucoș, 2001, 2009), history, sociology, etc. the education of children is closely in line with the environment in which they live; educated people have a culture that influences social and professional evolution, they show interest in knowledge and progress on the social scale. At the opposite pole are people who come from a subcultural environment, who have low self-esteem, show distrust of their own strengths, social vulnerabilities and lower interest in education and training. (Berezovski \& Chisari, 2011) The family environment greatly influences the students' openness to intercultural dialogue, 
interknowledge, discovering the material, cultural and spiritual values of those they come in contact with and belong to ethnic groups, other races, ethnicities or social categories. (Voinea, 2010) Intercultural education - as part of the "new education" (Nedelcu, 2007, 2008; Butnari, 2017) and an extension of school education begins in the family. (Cristea, 2009) The family is the social environment in which the child makes contact with the material, cultural and spiritual values, the first customs and traditions - but also with the prejudices or stereotypes that leave their mark on the education of the student. (Cuznetov, 2015)

Considering the developing personality of the student entering the school environment, the prejudices with which he comes from the family, (Verza, 2000) which generate the tendency of marginalization, social exclusion, segregation, racism or xenophobia (towards persons or minority groups), but also of the preponderant theoretical character of the school curriculum, we consider that the topic of forming the intercultural competence of the students from the gymnasium classes is topical and of maximum importance.

In the pedagogical experiment we demonstrated that extracurricular activities carried out systematically with non-formal and informal, in an organized environment, within the school-family-community partnership can lead to the formation of intercultural competence; thus, students will demonstrate a better knowledge of national cultural values, through the interdisciplinary approach of lessons in history, geography, Romanian language, technology education, foreign languages, etc., will demonstrate team spirit, moral-civic behavior, intercultural dialogue, tolerance, interaction, openness to communication and solidarity.

According to the research of the researcher (Gauthey, 1990) a person can relate well in an intercultural environment with the following qualities: empathy, flexibility, ability to help others, respect for the culture and values of those with whom they interact and belong to ethnic groups, they are of another religion, race, social condition, etc., the ability to accept that not all things are "black and white", but to have the power to understand the other with the uncertainty and friendliness of any social context.

Legislative documents from Romania, respectively Education Law 1/2011, New National Curriculum for primary and secondary education - 
necessary conceptualizations, approved in 2016, Recommendation of the European Parliament and of the Council, 18 December 2006 in Official Journal of the European Union, L394 / 10 , 30.12.2006 provide as the main purpose of education: the formation of integrity and the development of a set of skills, based on knowledge, skills and attitudes, which recommend the graduate for insertion in the labor market, in socio-cultural and economic life. European training profile for secondary school graduates according to the 2016 National Curriculum includes the following key competences: 1. Social and civic competences; 2. Communication skills in the mother tongue; 3 . Communication skills in modern languages; 4. Mathematical and basic skills in science and technology; 5. Digital competence; 6. Competence to learn to learn; 7. Competence for initiative and entrepreneurship; 8. Competence for cultural awareness and expression.

Researcher Lilia Pogolșa states in her specialized studies that have been undertaken in this regard, that "The school is called to offer, through intercultural education, a model of peaceful and constructive coexistence in a society in which I live in "Together with members of several ethnic groups." (Pogolșa, 2012) This is the premise behind our research, which will demonstrate that education and intercultural competence are formed in school, (Zaiţ, 2002) mainly through extracurricular, non-formal and informal activities, representing the path of communication to interaction, without prejudice, racism, xenophobia, actions of marginalization, social exclusion or segregation. (Ivasiuc, Koreck and Kovari, 2010).

The pedagogical model resulting from the research contributes to granting equal opportunities for all students (and people in general), regardless of race, ethnicity, religion, group membership, culture, etc.

Choice of experimental group (participants).

One of the research directions we focused on in the pedagogical experiment was closely related to the way in which the formation of intercultural competence influences formal, non-formal and informal activities. Thus, for the experiment group, which included: 6th grade B (24 students) and the control group: 6th grade A (26 students) we applied the "before and after" method, which highlights the changes that have occurred along the way, which have allowed to improve some activities or the teacher training program, facilitating the achievement of expected results and 
achieving the proposed purpose. The participants of the pedagogical experiment (who are students in the sixth grade of high school) are a leading indicator in the formation of intercultural competence, because at this age abstract thinking is solid, students discover real situations from the concrete circumstances of life, empathize and can make their own value judgement.

Development of the concept of competence. A number of researchers who have studied in fields such as pedagogy, psychology, sociology, history, etc. have referred to the concept of intercultural competence approached in close accordance with the concept of culture and interculturality, as this is a topical field. (Potolea \& Toma, 2010)

According to researchers (Dumbrăveanu, Pâslaru, Cabac, 2014; Dulamă \& Delory, 2011; Ray, 1999), the concept of competence has known several stages. In Romania, it was first used in vocational education, comprising the relationship between theoretical notions and their implementation, in a process in which the essential role belongs to the skills and attitudes of students. Subsequently, other valences in the teachinglearning-assessment process were assigned to the competence concept as follows:

1. between 1960 and 1970, the concept of 'competence' was mainly aimed at the formation of linguistic and communication competence, thus reflecting the student's ability to communicate correctly and coherently;

2. between 1970 and 1990, the competence concerned the area of management, communication and results obtained in the field of foreign languages;

3. the year 1990 brings a series of changes in the education system as a result of the stages of reforming the Romanian school; thus, in 2009 it is developed and applied to the National Curriculum focused on competencies and not on objectives as it was before 1990. The most brief approach would be: the transition from an objective-based education and mainly on didactic contents (knowledge acquired by students) to a curriculum that focuses on the student and his ability to apply theoretical notions at the end of a level of education, expressed in skills.

Approaching the concept of "competence" has been one of the constant concerns of specialists in the field (Pâslaru, 2003, 2011); thus over the years 
competence has been defined in over two hundred ways - and even now there is no unanimously accepted definition.

In Romania, the introduction of key competences in the National Curriculum (in 2016) is based not only on the need to reform the education system that operated according to the same principles of the 1970s, but also out of a desire to be in line with the educational policies of other European states; in this regard, in 2006 the Council of Europe Recommendation is addressed to the ministers of education of the countries of the European Union, regarding the competence-centered curriculum.

In the European literature, the concept of competence has a greater approach in the late 1980s - early 1990s, despite the fact that there have been constant reformulations and negative remarks on the conceptualization of competence.

Thus, the researcher (Cojocaru, 2017, p. 3) from the Republic of Moldova in specialized studies and scientific papers defines competence as: "a well-structured and thoroughly mastered system of knowledge, skills, abilities and attitudes".

In another scientific paper, researcher Cojocaru defines the concept of competence as follows: "Competence is a potential (cognitive, operational, affective-attitudinal, conative) that manifests itself successfully when the situation requires it" (Cojocaru, 2011, p. 3).

From the perspective of psychology, S,chiopu, U., defines: "Competence is a remarkable professional capacity, springing from knowledge and practice; it gives efficiency, precision, safety and allows solving difficult situations in the direction in which it was formed ". (Șchiopu, 1997, p. 69)

The author Goraș-Postică Viorica (2008, p. 47) defines the notion of competence as "an association of theoretical notions, aptitude and attitudinal acts in a given context".

Specialized studies, scientific papers and all literature in fields such as pedagogy, psychology, sociology, history, etc., address the concept of "competence" assigning different meanings as it results from the analysis of the works of well-known authors: Cucoș (2003); Cojocaru, Ticuță (2011); Cojocaru, Aștifenei (2019); Cojocaru, Vladu (2017); Ovcerenco, Sadovei, Papuc, Cojocaru-Borozan, (2014); Cucoş, Cozma (2001); Pâslaru (2011), 
Gremalschi (2015); Gillert (2003); Nedelcu (2008); Chiş (2005); Cucoş (2009); Pogolşa, Petrovschi, Samoilenco, \& Uzicov (2012); Cristea (2009) etc.

In the Education Law (2011) the concept of "competence" had a completely different meaning until 2014, essentially referring to the attributions and responsibilities of the institutions, authorities, officials, whose purpose was to implement the obligations according to the job description, "according to the area of competence" - aiming very little or not at all at the concordance between the information received by the students and their applicability. In the Education Code of the Republic of Moldova (until 2014) clarifications on the level of practical acquisitions that students should have at the end of an education cycle can be found in a very superficial way, which is improved by developing and implementing the New National Curriculum for primary and secondary education since 2016. In the late 1990s and early 2000s intercultural competence experienced a new approach in the works of Constantinovici (2007), Жуков (2005), which paid more attention to the level of theoretical acquisitions and the ability to perform certain operations, to the detriment of the emotional experiences or feelings that individuals have in general.

Another Russian researcher, Выготский (2003) shed new light on the value of communication, which leads to influencing people's quality of life, the superiority of interaction and not just the knowledge of cultural elements: "us-others".

Romanian researchers Zamfir, \& Vlăsceanu (1993), referring to intercultural competence stated in 1993: "a process by which a group receives, internalizes and applies values, norms, patterns of behavior or lifestyles specific to another group with which they are in contact".

This wording is closer to the situations in which migrants find themselves, as a phenomenon and issue on the table of political leaders worldwide this year.

According to the researcher Simensen (2003, apud Ciscai, p. 31) intercultural competence is "a fashion, a cliché used in the education system, although no one seems to know exactly what it means".

The Romanian researcher Constantin Cucoș (2003, p. 39) defines intercultural competence as: "the ability to change them, adapt their attitude, behavior and knowledge to the interaction with people belonging to other 
cultures". Also, in another scientific research paper, Professor Constantin Cucoș (Cucos 2009, p. 129) addresses the topic of intercultural competence, arguing that it "means that rational ability to relate to people belonging to other cultures, demonstrating permissiveness, respect and understanding of diverse cultural meanings ". In this sense, the researchers Gremalschi (2015) and Popescu (2013) also refer in his works of great value.

According to the author Ciscai (2008, p. 39) show that three stages must be completed for the formation of intercultural competence:

1.cognitive - the baggage of knowledge with which the student from the family environment comes to school;

2.affective - the feelings and emotions that the student experiences in the family and that accompany him during school;

3.behavioral - refers to the student's attitude, behavior, which is based on the two aspects listed above.

The problem of research with the title "Formation of intercultural competence of students in middle school" is defined by establishing the theoretical and applied foundations of intercultural education, which smooth the way to knowledge, acceptance, appreciation of culture, tolerance, solidarity, interaction and intercultural dialogue .

The object of the research consists in the formation of the intercultural competence of the students from the gymnasium classes, within the formal, non-formal and informal extracurricular activities, emphasizing the theoretical-applied fundamentals mentioned previously.

The research hypothesis is clearly and succinctly formulated: whether we will implement the conceptual, theoretical and practical delimitations according to our theme; if we introduce in the classes the team work activity, the activities based on free games, dances, music, thematic excursions, the exchange of experience within the Erasmus projects which include mobility in other states, socialization and mutual knowledge activities; by developing, applying and confirming the pedagogical model for the formation of intercultural competence - then there is a very high probability of forming intercultural competence for students in middle school.

The purpose of the research is to develop, apply and validate the pedagogical model for the formation of intercultural competence, in accordance with the theoretical-applied foundations of the proposed topic. 
Research objectives:

1.studying research in the field and discovering the basic concepts for the formation of intercultural competence;

2.knowledge of the evolution of the concept of intercultural education which is the foundation of the formation of intercultural competence;

3.specifying the factors and extracurricular activities of formal, nonformal, informal learning that underlie the formation of intercultural competence;

4.elaboration, application and verification of the pedagogical model for the formation of intercultural competence, according to the theoreticalapplicative foundations of the present thesis;

\section{Scientific research methodology}

The methodological research is based on the principles, theories and conceptions of pedagogy, social, school and family psychology, taking into account the studies, specialized works and theories of researchers in the field. (Ovcerenco, Gherman \& Untu, 2007; Ovcerenco, Sadovei, Papuc \& Cojocaru-Borozan, 2014)

Based on the questionnaires applied to parents, students and teachers, we could see to what extent intercultural education contributes to the formation of intercultural competence, implicitly to the formation of a behavior based on understanding, openness to communication, interaction, solidarity and tolerance. Given the two major phenomena (globalization and migration) that are the challenges of the modern world, we believe that regardless of the specialty in which he trained, the teacher should prove openness to interculturality and train students in social and intercultural skills. The dynamics of the entrepreneurial segment has shown that in most of them entrepreneurs have a greater openness than candidates who opt for a job if they prove social and intercultural skills in a higher percentage compared to those who are just good specialists.

The theoretical landmarks that formed the basis of our research are: culture, intercultural education, intercultural competence, which are approached generously in the scientific research works of the authors. The concept of intercultural education is found in the specialized works of several researchers, among whom we cite: Abdallah-Pretceille, (1999); Butnari, 
(2017); Ciobanu \& Cozărescu (2010); Ciscai \&Marchiș (2008); Cucoș (2009); Cucoş, Cozma (2001); Goraş-Postică (2003); Ivasiuc, Koreck \& Kovari (2010); Nedelcu (2008); Plugaru, Pavalache (2008); Pogolşa, Petrovschi \& Samoilenco, Uzicov (2012); Ray (1999); Rus (2002); Rus, Bota, (2002); Voinea, (2010).

The concept of competence is treated with the utmost seriousness by researchers in specialized studies, scientific papers and in all literature in fields such as pedagogy, psychology, sociology, history, etc. Thus, the concept of "competence" is assigned different meanings as it results from the analysis of the works of well-known authors: Cucoș (2003); Cojocaru, Ticuță (2011); Cojocaru, Aștifenei (2019); Cojocaru, Vladu (2017); Ovcerenco, Sadovei, Papuc \& Cojocaru-Borozan, (2014); Cucoş \& Cozma (2001); Pâslaru (2011); Gremalschi (2015); Nedelcu (2008); Chiş (2005); Cucoş (2009); Pogolşa, Petrovschi, Samoilenco, Uzicov (2012); Ovcerenco, Gherman, Untu (2007); Guţu, (2014); Sadovei (2008); Sadovei, Papuc, Cristea, Cojocaru-Borozan (2016); Sadovei, Cojocaru-Borozan (2014) etc.

In approaching the concept of the concept of intercultural competence, the specialists in the field stood out: Dulamă (2011); Fantini (2007); Hofstede (1996); Dumbrăveanu, Pâslaru, \& Cabac (2014); Voinea (2010); Zait (2002); Rus (2002); Popescu (2013); Poledna, Ruegg, \& Rus (2003);

The conceptual approach of family education is found in the works of Cuznetsov researchers (2010, 2013, 2015, 2016); Șchiopu (1997); Verza (2000);

The basis of our research were the epistemological landmarks according to the legislative acts, among which we mention:

1. Recommendation of the European Parliament and of the Council of 18 Dec. 2006 in Official Journal of the European Union, L394 / 10, 30.12 .2006 on the description of key competences; ; (art. 10, 12, 14)

2. The new National Curriculum for primary and secondary education necessary conceptualizations, approved in 2016. p. 47-49

3. Education Law of the Republic of Moldova, no. 547 of 21.07.1995 published in the Official Gazette, no. 62-63 of 09.11.1995, Art. No. 692. 15. (art. 5, 27) 
4. Education Code of the Republic of Moldova. Code no. 152 of 17.07.2014. Official Gazette, no. 319-324 of 24.10.2014, Art. No. 634. (art. 2, 5, 6, 7, 36)

5. Framework Convention for the Protection of National Minorities, document available

at http://www.anr.gov.ro/docs/legislatie/internationala/Conventia_Cadru _pentru_Protectia_Minoritatil or_Nationale.pdf, (accessed in April 2020); Art. 32, 34, 41;

6. International Convention on Economic, Social and Cultural Rights, Art. 13, p. 4, conf. Ivasiuc A., Koreck M., Kovari R., "Together" Agency, Institute for the Study of National Minority Issues, Intercultural Education, from theory to practice", 2010;

The research methods and tools implemented in our research are:

- theoretical: scientific documentation, analysis and systematization of scientific data

- praxiological: pedagogical observation; application tests, questionnaires, interview guide;

- hermeneutics: interpretation of scientific data;

- experimental: pedagogical experiment;

- statistics and mathematics: mathematical analysis of statistical data.

By implementing praxiological methods: application tests, questionnaires, interview guide, etc. the aim is to determine to what extent the elements of culture that underlie the "iceberg of culture" are found in the attitude, behavior and social and intercultural skills of students (norms of life, moral and spiritual values, respect, punctuality, communication, leisure management, honesty, faith, family, friendships and hierarchical relationships, division of labor, etc.) Equal attention is paid to the elements of surface culture (language, gastronomy, clothing, greeting, social conduct, music, dance, arts, literature, theater, architecture, etc.) which is based on culture from the depths of the iceberg of culture.

The direct observation method facilitated the detection of changes in students' attitudes, so that through the implementation of the knowledge acquired and the means at their disposal in the school environment they can form intercultural competence. At the age of preadolescence (which ends at 12-13 years) students "face" a series of changes, whether emotional, 
physical or intellectual. Thus, their behavior changes and adapts to meet other challenges; they start to have a higher self-esteem, they try new friends, they communicate more, they are preoccupied with the group of friends mainly in the virtual environment, directing time resources to social networks (Facebook, Instagram, Tik-Tok, etc.), want to meet new people, discover the beauty of the world around them through trips, camps, study visits, educational projects based on experience exchange, volunteer actions, etc. All these resources can contribute to the formation of intercultural competence, if they are managed with professionalism and teacher vocation, regardless of the chosen specialization, within the SchoolFamily Partnership. (Dorobantu-Dina, 2019).

Description of instruments for assessing intercultural competence: questionnaire, measurement scale, sociometric tests, etc. Scientific novelty and originality. The research work finds its utility in secondary education, a situation in which students are in the process of knowing and identifying the spectrum of activities for the formation of intercultural competence. In this sense, we have included the theoretical-applied landmarks indispensable for the formation of a moral-civic behavior, for a better theoretical training of students, which leads to the formation of skills necessary for social and intercultural skills. Essentially, the novelty and originality of the title research "The formation of intercultural competence for students in middle school classes" resulted in: the delimitation of the basic concepts necessary for the formation of intercultural competence; presentation of the history of intercultural education, competence and intercultural competence; the approach from a historical, social, psychological, pedagogical perspective of the formation of intercultural competence, emphasizing the importance of extracurricular activities, such as: teamwork or pairs, social-charitable and entrepreneurial actions, educational mini-projects based on experience exchange, team sports activities, excursions, planting of trees and ornamental shrubs, technical-application competitions, celebrations, free games, folk or modern dances, knowledge of traditions and values specific to ethnic groups, people belonging to another race, religion, culture or have another socioeconomic and cultural level. Also, as an element of novelty and scientific originality in this paper is the elaboration, application and confirmation of the Pedagogical Model. training intercultural competence in middle school 
students; promoting the elements underlying the formation of intercultural competence; highlighting the factors and activities on which the research problem is best formed.

The theoretical significance of the research consists in the analysis, description, explanation and delimitation of the conceptual framework for the formation of intercultural competence; Given the research and analysis of concrete situations related to intercultural education, we aimed to specify the theoretical landmarks necessary for the formation of intercultural competence and the appropriate framework for its training in secondary education. Taking into account the need for the formation of intercultural competence, supported by the problems of today's world, of which we mention here only the phenomenon of globalization and migration - which intensified with Romania's accession to the European Union on January 1, 2007, we support the importance of intercultural competence for smoothing communication between people, solidarity, openness to communication and prosocial interaction.

In other words, we argue that the theoretical significance of research with the title "Training intercultural competence of students in middle school" is based on: holistic approach to intercultural education, which allowed us to establish the theoretical and applied foundations in training intercultural competence, as well as their delimitation during extracurricular, formal, nonformal and informal activities; elaboration, application and scientific verification of the Pedagogical Model training in intercultural competence, which led to better communication between students, mutual aid, better school results, integration and solidarity, openness to knowledge of the cultural values of those belonging to another culture, ethnicity, race, religion, etc.

\section{The Model and Findings}

The applicative value of the research is the date of attestation of the pedagogical tools that highlight the usefulness of the Pedagogical Model for the formation of intercultural competence, whose quality is a holistic one, representing equally a guide for conducting intercultural education classes and not only, which can lead to better school results and intercultural, prosocial behavior. 
The Optional at the school's decision was also elaborated and implemented with the title: "Moral behavior through intercultural communication" with addressability to the sixth grade students; the establishment of the "Diamond" Theater Troupe of the "I.C. LĂZĂRESCU "Țițești, Argeș County (Romania), a band that was awarded in the National Contest with direct participation“ My Intercultural Journey ", held in the city of Oradea (Romania), 2019; elaboration and application of the Guide for the training of teachers from the perspective of education and intercultural competence; specialized studies, scientific papers and theoretical-applied foundations of specialists in the field, which support the formation of intercultural competence of students in middle school classes; obtaining the research objectives and validating the pedagogical experiment, undoubtedly lead to the formation of a moral-civic and intercultural behavior of the students.

Implementation of scientific results. The pedagogical experiment respected the three obligatory stages: the stage of ascertaining, training and verifying the Pedagogical Model of training the intercultural competence of the students from the gymnasium classes. The scientific research process, which was intentionally challenged to establish the context in which intercultural competence is formed for students in middle school classes under predetermined conditions, included 100 students. Initially, the number of respondents in middle school classes was 110 students; of these, six students had a fluctuating attendance at school, as a result of going abroad for seasonal work with their family, three students got married at the end of the sixth grade and did not continue their classes and one student transferred to another school. The preparatory research included: 50 teachers, 100 parents and 50 sixth grade students from the I.C. LĂZĂRESCU” Țițești, Argeș County (Romania). The sixth grades were established randomly at the beginning of the 2018-2019 school year. Experimental group: 6th grade B (24 students); control group: 6th grade A (26 students).

The implementation of the scientific results generated by the pedagogical experiment are supported by the elaboration and application of the Guide for the training of teachers from the perspective of education and intercultural competence; elaboration and application of specialized studies and articles presented in national and international workshops, by participating in a series 
of national and international conferences and especially by the multitude and diversity of extracurricular activities with students.

The scientific results obtained highlight the fact that there is a close connection between the theoretical-applied foundations and the pedagogical model for the formation of intercultural competence; as a result of the elaboration, application and verification of the Pedagogical Model of intercultural competence has shown that middle school students are interested in knowing, discovering, preserving and promoting their own cultural values and also the cultural values of those with whom they interact with; students who are of another ethnicity, race, religion, social condition; It was found that extracurricular activities lead to the formation of intercultural competence giving students the opportunity to demonstrate tolerance, acceptance, interaction, solidarity and open communication without prejudice, stereotypes, marginalization, social exclusion, segregation, discrimination or racism.

\section{Conclusions}

In this research we referred to the topic of intercultural education, which is one of utmost importance and topicality in the context of two major global issues: the phenomenon of globalization and migration. The formation of intercultural competence for middle school students is the desideratum contained in the educational policies entitled "new education", which can contribute to solving some of the burning problems of today's society. Delimiting the theoretical aspects, carrying out the pedagogical experiment and processing qualitatively and quantitatively the results obtained, I formulate the following conclusions:

1. Based on the analytical study in the field of the research problem, we defined and exposed the essence of the basic concepts, namely: culture, intercultural education, competence, intercultural competence. We made an analysis of the evolution of intercultural education, which contributed to the clarification of epistemological guidelines regarding intercultural competence.

2. The theoretical study and highlighting the current problems faced by the school, family and society as a whole related to intercultural 
education, led to the specification and description of the formation of intercultural competence of students in middle school classes.

3. Collaboration with parents based on the Educational Partnership, can contribute to a better functionality of the relations between school and family, respectively to the formation of intercultural competence and to solving some of the problems of today's world, respectively the phenomenon of globalization and migration.

The scientific problem and the purpose of the research were solved by achieving the following objectives:

- specifying the conceptual and theoretical framework of intercultural education by highlighting the basic concepts;

- studying the staged evolution of intercultural education that contributes to the formation of intercultural competence of students in middle school classes;

- the interdisciplinary approach of intercultural education that can lead to the formation of intercultural competence;

- establishing the psycho-pedagogical conditions that lead to the formation of intercultural competence of students in middle school classes. Based on the above, the following recommendations are required:

- approaching intercultural education in a sustained and creative way through written media, audio-tv and through social communication networks, blogs, you tube, etc.

- capitalization of formal and non-formal activities regarding the involvement of students in activities specific to intercultural education, based on normative acts initiated by educational policies at national level;

- the training of teachers from the perspective of approaching intercultural education, as a discipline recently introduced in the national curriculum, included in the "new education", as an alternative to solve some of the problems of today's world, including of course migration and globalization.

- the need to develop teaching aids, guides for teachers, to support the understanding of the importance of intercultural education and the need to train intercultural competence in middle school students; 
- promoting activities related to intercultural education on the school's Facebook page;

- initiating and supporting the partnership between school and family as well as with other institutions, which can lead to a more efficient approach to intercultural education and implicitly to the formation of intercultural competence;

- based on the research undertaken, we sometimes found limits that led to some difficulties: on the part of the parents, most of the mothers responded to our requests, in a percentage of $80 \%$. A Project of intercultural activities with parents could not materialize. Teachers are reluctant when they choose to attend training courses with personal financial support.

However, we believe that this research is a starting point in studying the components that can lead to the formation of intercultural competence in middle school students and can be the basis for analyzing how to initiate and develop intercultural competence.

Researchers Cuznetov (2004) and Guțu (2008) from the Republic of Moldova argue in scientific papers that the family environment makes its mark on the formation of the child's behavior, so that it is influenced by what he sees or hears in the house. Often the family environment is where the student comes into contact with prejudices, stereotypes, attitudes of social exclusion or marginalization of those who belong to ethnic groups or are of another race, religion, social condition, etc. Through his attitude, the teacher can contribute to the formation of intercultural competence, as a vector of opinion or behavioral model; examples from personal life, beautiful speech, paraverbal language, initiation and development of formal or non-formal extracurricular activities encourage and support the formation of intercultural competence of students in middle school classes.

Starting from the premise that intercultural education is the transdisciplinary discipline that underlies the formation of intercultural competence, we appreciate that this is not only the desideratum of the Romanian education system focused on the formation of key competences, but is a condition for integrating young people into social and professional life; by forming the intercultural competence we come to the support of solving the problem of the current world, namely the limitation of 
xenophobia, discrimination, racism, segregation on ethnic, cultural, social criteria, etc. (Musteață, 2006).

\section{References}

Abdallah-Pretceille, M. (1999). L'education interculturelle, PUF, Paris.

Antonesei, L. (1996). Paideia. Fundamentele culturale ale educaţiei., Iaşi, Polirom.

Batelaan, P. (2003). Le nouveau defi interculturel lance a l'education: la diversité religieuse et le dialogue en Europe, (DGIV/EDU/DIAL (2003), Consiliul Europei, Strasbourg.

Berezovski, N., Chisari L. (2011). Atitudinile și credințele parentale - factor prerogativ al educației interculturale a personalității în devenire, Psihologie 1, https://cupdf.com/document/revista-psihologie-nr-12011.html

Butnari, N. (2017). Noile Educații. Suport de curs, Universitatea de Stat Moldova, Chișinău, CEP - USM.

Cebanu, L. (2014). Tendințe moderne în formarea inițială a cadrelor didactice. Revista științifică a Universității de Stat din Moldova, 5(25).

Chiş, V. (2005). Pedagogia contemporană, pedagogia pentru competenţe, Cluj. Ciobanu, O. \& Cozărescu M. (Eds.) (2010). Manual de educaţie interculturală, Editura ASE, Bucureşti.

Ciscai, L., Marchiș I. (2008). Educația interculturală și multimedia, Editura Presa Universitară Clujană.

Cojocaru, V., Ticuță E. (2011). Competențe anteprenoriale prin metode interactive, Ghid metodic, Editura Pontos, Chișinău.

Cojocaru, V., Valdu, M. (2017). Competențe decizionale ale managerilor în implementarea inovațiilor, Universitatea de Stat din Tiraspol, Chișinău.

Cojocaru, V., Aștifenei, R. (2019). Competențe de negociere educațională a managerului din învățământul preuniversitar, Universitatea de Stat din Tiraspol, Chișinău.

Constantinovici, E. (2007). Limbaj și comunicare. În Comunicare publică: concept și interpretări, CEP USM, Chișinău, 7, 59-70.

Cristea, G. (2009). Pedagogie Generală, EDP, București.

Cucoș, C. (2009). Educația. Dimensiuni culturale și interculturale, Editura Polirom, Iași.

Cucoş, C., Cozma, T. (2001). Locul educaţiei pentru diversitate în ansamblul problematicii educaţiei contemporane. In T. Cozma (Eds.), O nouă provocare pentru educaţie: interculturalitatea, Editura Polirom, Iaşi. 
Cucoş, C. (2003). Pluralismul valoric şi exigenţele educaţiei interculturale, în Didactica Pro, Revista de istorie şi practica educaţională, nr. 4-5, 20-21. Cuzneţov, L. (2004). Modelul pedagogic al educaţiei pentru familie, Intellectus, 4, 59-63.

Cuzneţov, L. (2010). Educaţie prin optim axiologic. Teorie şi practică. UPS „Ion Creangă”, Chişinău.

Cuzneţov, L. (2013). Pedagogia şi psihologia familiei. Suport de curs. Editura Primex-Com, Chişinău.

Cuzneţov, L. (2015). Educaţia pentru timpul liber al familiei: unele repere teoretice, metodologice şi aplicative, Editura UPS „Ion Creangă”, Chișinău.

Dorobantu-Dina, R. (2019). Comunicarea interculturală - factor al optimizării procesului instructiv-educativ. Simpozionul Internaţional Comunicarea interculturală în situaţii educaţionale: cunoaştere metode - competenţe didactice, Editura Else, Craiova, 307-316. https://www.didactic.ro/stiri/simpozion-international-53

Dulamă, M., Delory C. (2011). Despre competențe. Teorie și practică, Editura Presa Universitară Clujană, Cluj Napoca.

Dumbrăveanu, R., Pâslaru, VI., Cabac, V. (2014). Competenţe ale pedagogilor: Interpretări. Chişinău.

Education Law 1/2011, publication in the Official Gazette, Part I no. 18 of January 10, 2011, articles 3-4, 10, 19, 45, 47, 48.

Education Law of the Republic of Moldova, no. 547 of 21.07.1995, Official Gazette, 62-63 of 09.11.1995, Art. No. 692. 15.(art. 5, 27)

Education Code of the Republic of Moldova. Code no. 152 of 17.07.2014.

Official Gazette, 319-324 of 24.10.2014, Art. No. 634. (art. 2,5,6,7,36) European Parliament (2006). Recommendation of the European Parliament and of the Council of 18 Dec. 2006 in Official Journal of the European Union, L394 / 10, 30.12.2006 on the description of key competences; (art. 10, 12, 14)

Fantini, A., E. (2007). Exploring and assessing intercultural competence, Center for Social Development, Global Service Institute.

Framework Convention for the Protection of National Minorities, document available at

http://www.anr.gov.ro/docs/legislatie/internationala/Conventia_Cadru_pentr u_Protectia_Minoritatil or_Nationale.pdf, (accessed in April 2020); Art. 32, 34, 41;

Gauthey, F., Xardel, D. (1990). Le management interculturel, Presses Universitaires de France, Paris. 
Goraş-Postică, V. (2003). Educaţie interculturală în Republica Moldova, Editura Arc, Chişinău.

Gremalschi, A. (2015). Formarea competenţelor-cheie în învăţământul general: Provocări si constrângeri. Studiu de politici educaţionale, Editura Arc, Chişinău.

Guţu. Vl. (Eds.) (2008). Psihopedagogie centrată pe copil. CEP USM, Chişinău, 2008.

Guțu, V1. (2011). Învățământul centrat pe competențe: abordare teleologică. Didactica Pro, 1(65), 2-7.

Guţu, Vl. (2014). Curriculum centrat pe competenţe: orientări de optimizare/dezvoltare continuă. Didactica Pro, 3(85), 6-10.

Hofstede, G. (1996). Managementul structurilor multiculturale, Editura Economică, Bucureşti.

International Convention on Economic, Social and Cultural Rights, Art. 13, p. 4, conf. Ivasiuc A., Koreck M., Kovari R., “Together” Agency

Institute for the Study of National Minority Issues, Intercultural Education, from theory to practice", 2010;

Ivasiuc, A., Koreck, M., Kovari, R. (2010). Educația interculturală: de la teorie la practică, Convenția Internațională privind drepturile Economice, Sociale şi Culturale, Editura Institutul Intercultural, Timișoara.

Lupșa, D. (2019). Manual de educație socială pentru clasa a VI-a, Editura Didactică și Pedagogică, București.

Maliţa, M. (2002). Zece mii de culturi o singură civilizaţie, Editura Nemira, București.

Musteaţă, S. (2006). Educaţia cetăţeniei democratice şi toleranţei prin intermediul istoriei. Ghid didactic, Editura Cartdidact, Chişinău.

Nedelcu, A. (2007). Educaţie democratică, incluziune şi interculturalitate. Editura Didactică şi Pedagogică, Bucureşti.

Nedelcu, A. (2008). Fundamentele educaţiei interculturale: diversitate, minorităţi, echitate, Editura Polirom Iaşi.

Ovcerenco, N., Sadovei, L., Papuc, L., Cojocaru-Borozan, M. (2014). Fundamentele Științelor Educației, Manual universitar, Tipografia UPS „Ion Creangă”, Chișinău.

Ovcerenco, N., Gherman, V., Untu, V. (2007). Pedagogia. Note de Curs, Tipogrfia „Reclama”, Chișinău.

Pâslaru, Vl. (2003). Principiul pozitiv al educaţiei, Editura Civitas, Chişinău. Pâslaru, Vl. (2011). Competenţa educaţională - valoare, obiectiv şi finalitate. Didactica Pro, 2, 4-8.

Plugaru, L., Pavalache, M. (2008). Educație interculturală, Editura Psihomedia, Sibiu. 
Pogolşa, L., Petrovschi, N., Samoilenco, V., Uzicov, N. (2012). Educaţie interculturală. Curriculum şcolar. Clasele I - IX. Bons Offices, Chişinău.

Poledna, R., Ruegg, F., Rus, C. (2003). Interculturalitate. Cercetări şi perspective romaneşti, Presa Universitară Clujeană, Cluj-Napoca.

Popescu, S. (2013). Comunicarea interculturală, Editura Institutului European, Iaşi.

Potolea, D., Toma S. (2010). Competența. Concept și implicații pentru programele de formare a adulților, publicat în volumul III al Conferinței naționale de Educație a Adulților, Editura Eurostampa, Timișoara.

Ray, C. (1999). Educația interculturală - experiențe, politici, strategii, Editura Polirom, Iași.

Rus, C. (2002). Educaţia interculturală - modalităţi de concretizare şi evitarea tentatiilor culturaliste, în Institutul Intercultural Timişoara, Educaţie interculturală in comunităţi multietnice, Editura Institutul Intercultural, Timişoara.

Rus, C., Bota, O. (2002). Educație interculturală în comunități multietnice, Editura Institutul Intercultural Timișoara.

Sadovei, L., Papuc, L., Cristea, S., Cojocaru-Borozan, M. (2016). Teoria și praxiologia cercetării pedagogice, Editura Didactică și Pedagogică, București.

Sadovei, L. (2008). Formarea competenței de comunicare didactică prin modulul pedagogic universitar, [Doctoral dissertation, Pepperdine University]. Editura Arc, Chișinău.

Sadovei, L., Cojocaru-Borozan, M. (2014). Fundamentele ştiinţelor educaţiei, UPS „Ion Creangă”, Chişinău.

Schiopu, U. (1997) coordonator. Dicționar de Psihologie, Editura Babel, București.

Verza, E., Verza, F. (2000). Psihologia vârstelor, ProHumanitate, București.

Voinea, M. (2010). Educație interculturală - Suport de curs, Editura Universitatea Transilvania din Brașov.

Zaiţ, D. (2002). Management intercultural. Valorizarea diferenţelor culturale, Editura Economică, Bucureşti.

Zamfir, C., Vlăsceanu, L. (coord.) (1993). Dicţionar de sociologie, Editura Babel, Bucureşti.

Выготский, Л.С. (2005), Психология развития человека. Москва: Смысл. 